\title{
PLEIOTROPIC GENE AND ITS INFLUENCE ON STEM, PETIOLE AND BRACT TIP PIGMENTATION IN SUNFLOWER (Helianthus annuus L.)
}

\author{
T.V. Deveraja ${ }^{*}$ and Shanker Goud \\ College of Agriculture and Regional Agricultural Research Station, \\ Raichur 584101, India
}

Received: January 14, 2005 Accepted: November 22, 2005

\author{
SUMMARY
}

\begin{abstract}
The inheritance of stem, petiole and bract tip color was studied in the cross $c m s-103 \mathrm{~A} \times \mathrm{PFNB}-2 . \mathrm{F}_{1}$ studies revealed that purple color of stem, petiole and bract tip is dominant over green color of these plant parts. Complementary gene action was observed for these characters in $F_{2}$. The genes governing the inheritance of stem, petiole and bract tip colors were designated as Ptla and Psmb, Ptla and Ptlb, Ptla and Pbtb, respectively, the gene Ptla being common to all three traits.
\end{abstract}

Key words: sunflower, inheritance, stem color, petiole color and bract tip color

\section{INTRODUCTION}

The knowledge of the inheritance of various characters is of paramount importance for achieving success in plant breeding. The knowledge of interrelationships of morphological traits viz., stem color, petiole color and bract tip color could be a valuable help to the breeder to directly select superior genotypes for desirable traits. In hybrid seed production, markers are very useful, as they help breeders to detect admixtures and contaminants and to maintain genetic purity of the crop. Qualitative genetics has direct applications in plant breeding. The knowledge of inheritance of various qualitative characters is a prerequisite for plant breeding in any crop. The objective of the present investigation on sunflower was to study the inheritance of stem, petiole and bract tip color.

\section{MATERIAL AND METHODS}

The experimental material for the study comprised of two inbreeds having contrasted color traits viz., cms-03A (green) and PFNB-2 (purple). Both direct and

* Corresponding author 
reciprocal crosses were made during kharif 2003-04. The $\mathrm{F}_{1}$ and $\mathrm{F}_{2}$ progenies were raised during subsequent seasons at the Regional Agricultural Research Station, Raichur, Karnataka.

The data on the inheritance of stem, petiole and bract tip color were recorded from the parents, $F_{1}$ and $F_{2}$ generations of the cross cms-103A $\times$ PFBN-2. The $F_{2}$ population consisted of 1448 plants. The $\chi^{2}$ test was employed to work out the proportion of segregation for each character under study. Gene symbols were used as per recommendations of the International Committee on Genetic Symbols and Nomenclature (Tanaka, 1957). The $\mathrm{F}_{1}$ of the reciprocal cross PFBN-2 $\times 103 \mathrm{~B}$ showed purple color for all the three traits, but all the plants exhibited male sterility, hence the reciprocal cross could not be advanced to the $\mathrm{F}_{2}$ generation.

\section{RESULTS AND DISCUSSION}

Crossing has been made between two inbreds viz., cms-103A and PFNB-2 having contrasting morphological trait color (green and purple). The female parent cms-103A had green stem, petiole and bract tip, while the male parent PFNB-2 had purple stem, petiole and bract tip. The results indicated that in the $\mathrm{F}_{1}$ generation all plants showed purple stem, petiole and bract tip revealing the dominance of purple color (Table 1).

Table 1: Three contrasted color characters of parents and their $\mathrm{F}_{1} \mathrm{~s}$ in sunflower

\begin{tabular}{lcccc}
\hline \multirow{2}{*}{ SI. No. } & Character & \multicolumn{2}{c}{ Parent } & \multirow{2}{*}{$\mathrm{F}_{1}$} \\
\cline { 3 - 4 } & & $c m s-103 \mathrm{~A}$ & PFNB-2 & \\
\hline 1 & Stem color & Green & Purple & Purple \\
2 & Petiole color & Green & Purple & Purple \\
3 & Bract tip color & Green & Purple & Purple \\
\hline
\end{tabular}

Table 2: Phenotypic segregation for three morphological in the $\mathrm{F}_{2}$ generation of the cross cms$103 \mathrm{~A} \times$ PFNB-2 in sunflower

\begin{tabular}{lcccccc}
\hline \multirow{2}{*}{ Character } & \multirow{2}{*}{ Obs/Exp } & \multicolumn{2}{c}{$\mathrm{F}_{2}$} & \multirow{2}{*}{ Ratio } & \multirow{2}{*}{$\chi^{2}$} & \multirow{2}{*}{ P value } \\
\cline { 2 - 4 } Stem color & Obs & 796.00 & 652.00 & & & \\
\multirow{2}{*}{ Petiole color } & Exp & 814.50 & 633.50 & $9: 7$ & 0.9604 & $0.5-0.3$ \\
& Obs & 796.00 & 652.00 & & & \\
\multirow{2}{*}{ Bract tip color } & Exp & 814.50 & 633.50 & $9: 7$ & 0.9604 & $0.5-0.3$ \\
& Obs & 796.00 & 652.00 & & & \\
& Exp & 814.50 & 633.50 & $9: 7$ & 0.9604 & $0.5-0.3$ \\
\hline
\end{tabular}

Obs: observed frequency

Exp: expected frequency

$P$ value: probability value

The $\mathrm{F}_{2}$ generation was raised by selfing $\mathrm{F}_{1}$ plants. Out of $1448 \mathrm{~F}_{2}$ plants raised, 796 plants showed purple stem, petiole and bract tip and 652 plants had green stem, petiole and bract tip. Calculations showed that the ratio of purple color to 
green color plants was approximately 9:7 (Table 2). Segregation of stem, petiole and bract tip color showed that these characters were controlled by two complementary genes. The dominant purple color on stem, petiole and bract tip is expressed only when both genes are dominant. If either of them or both are recessive, the green color is expressed. The shi-square test against the 9:7 ratio was non-significant. The non-significance of the chi-square test indicates close agreement between the observed and expected ratios and the segregation value was valid and considered as good fit.

\section{Joint segregation of characteristics in the $\mathrm{F}_{2}$ generation}

Joint segregation data (Table 3) revealed the existence of pleiotropy for pigmentation on the stem, petiole and bract tip involving a single gene.

Table 3: Phenotypic joint segregation for three morphological characters in the $\mathrm{F}_{2}$ generation of the cross cms-103A $\times$ PFBN-2 in sunflower

\begin{tabular}{|c|c|c|c|c|c|c|c|c|}
\hline \multirow{2}{*}{ Character with ratio } & \multirow{2}{*}{$\mathrm{F}_{2}$ joint ratio } & \multirow{2}{*}{ Obs/Exp } & \multicolumn{4}{|c|}{ Joint segregation } & \multirow{2}{*}{$\chi^{2}$} & \multirow{2}{*}{$P$ value } \\
\hline & & & $\overline{A B}$ & $A b$ & $\mathrm{aB}$ & $a b$ & & \\
\hline \multirow{3}{*}{$\begin{array}{l}\text { Stem color }(9: 7) \text { with } \\
\text { petiole color }(9: 7) \text { and } \\
\text { bract tip color }(9: 7)\end{array}$} & & Obs & 605.00 & 191.00 & 229.00 & 423.00 & & \\
\hline & $81: 63: 63: 49$ & Exp Ind & 458.16 & 356.34 & 356.34 & 277.16 & 246.02 & \\
\hline & $27: 9: 9: 19$ & Exp* & 610.87 & 203.62 & 203.62 & 429.87 & 4.11 & $0.3-0.2$ \\
\hline \multirow{3}{*}{$\begin{array}{l}\text { Petiole color (9:7) with } \\
\text { bract tip color }(9: 7) \text { and } \\
\text { stem color }(9: 7)\end{array}$} & & Obs & 605.00 & 191.00 & 229.00 & 423.00 & & \\
\hline & 81:63:63:49 & Exp Ind & 458.16 & 356.34 & 356.34 & 277.16 & 246.02 & \\
\hline & 27:9:9:19 & Exp* & 610.87 & 203.62 & 203.62 & 429.87 & 4.11 & $0.3-0.2$ \\
\hline \multirow{3}{*}{$\begin{array}{l}\text { Bract tip color (9:7) with } \\
\text { petiole color }(9: 7) \text { and } \\
\text { stem color }(9: 7)\end{array}$} & & Obs & 605.00 & 191.00 & 229.00 & 423.00 & & \\
\hline & $81: 63: 63: 49$ & Exp Ind & 458.16 & 356.34 & 356.34 & 277.16 & 246.02 & \\
\hline & 27:9:9:19 & $\operatorname{Exp}^{\star}$ & 610.87 & 203.62 & 203.62 & 429.87 & 4.11 & $0.3-0.2$ \\
\hline
\end{tabular}

Obs: observed frequency

Exp Ind: expected frequencies on independent basis

Exp*: expected frequencies when one gene is common

The pleiotropic nature of this gene and its interrelationship with other genes is shown in Figure 1. The joint ratio of 18:63:63:49 for petiole with stem, petiole with bract-tip and stem bract tip color was modified into 27:9:9:19 as one gene was common among the characters.

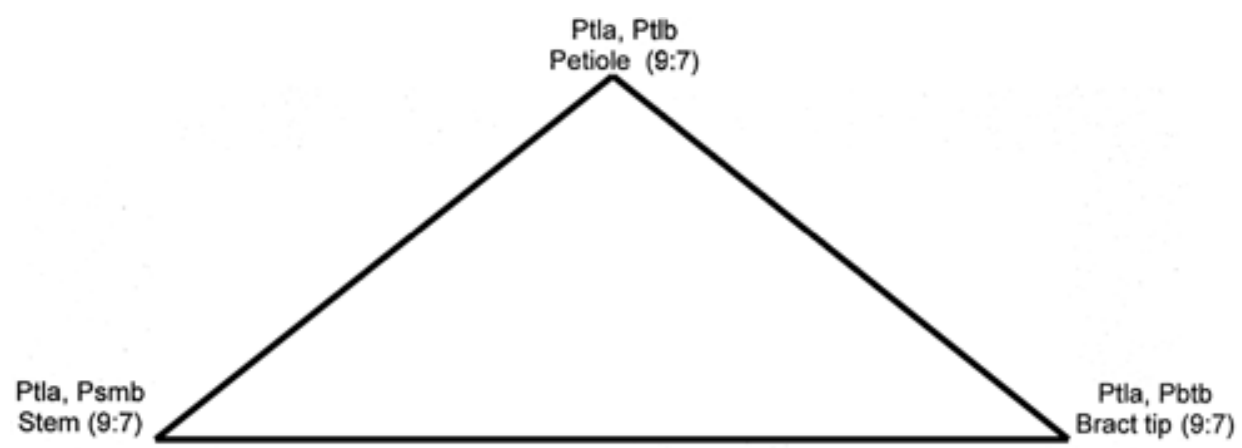

Figure 1: Pleotropic gene for three characters of the cross cms-103A $\times$ PFNB-2 in sunflower 
The factors controlling petiole color were designated by the gene symbols Ptla and Ptlb. One of these two complementary genes of petiole coloration, Ptla, was common for the pigmentation of the stem, petiole and bract tip. This pleiotropic gene acted as basic complementary gene and it was responsible for the expression of color of the aforementioned plant parts, in combination with genes for other characters. Taking Ptla as the pleitropic gene, the gene symbols for the three vegetative characters were as follows:

1. stem - Ptla, Psmb

2. petiole - Ptla, Ptlb

3. bract tip - Ptla, Pbtb.

Unrae (1974), Leclercq (1968) and Stoenescu (1974) reported a monogenic control of stem color but the cross between $c m s-103 \mathrm{~A} \times$ PFBN-2 has revealed that it is digenically controlled, with a complementary gene action. A ratio of 9 purple : 7 green for petiole color was reported by Joshi et al., 1994. The present study also reveals that petiole color was controlled by two complementary genes. There are no previous reports available on the inheritance of bract tip color and the present finding concerning the interaction of two complementing genes, appears to be first of its kind.

\section{ACKNOWLEDGEMENTS}

This work was carried out under NATP Mission Mode Project on the Hyderabad Crops (sunflower) RARS, Raichur Centre. The authors are grateful to the project for providing the facilities.

\section{REFERENCES}

Joshi, S.S., Basavalingappa and Giriraj, K., 1994. Pleiotropy in sunflower (Helianthus annuus L.). Helia 20: 1-6.

Leclercq, P., 1968. Inheritance of some qualitative characters in sunflower. Annales de Amelioration des Plantes 18: 307-315.

Stoenescu, F., 1974. Sunflower Science and Technology. J.F. Carter (Ed.) Agronomy Monograph, American Society of Agronomy, Madison, Wi., No. 19: 279-338.

Tanaka, Y., 1957. Report of the International Committee of Genetic Symbols and Nomenclature Union. International Union of Biological Sciences, News Letter 30: 6. 


\title{
GEN PLEIOTRÓPICO Y SU INFLUENCIA EN LA PIGMENTACIÓN DEL TALLO, PECÍOLO Y PICO DE LA BRÁCTEA EN GIRASOL (Helianthus annuus L.)
}

\author{
RESUMEN
}

La herencia del color del tallo, el pecíolo y el pico de la bráctea, era estudiada en el cruzamiento cms-103 A $\times$ PFNB-2. El estudio de la generación $\mathrm{F}_{1}$ mostró que el color violeta del tallo, el pecíolo y el pico de la bráctea era dominante en relación con el color verde de dichas partes vegetales. Fue observada la acción complementaria de genes para estas propiedades en la generación $\mathrm{F}_{2}$. Los genes que dirigían la herencia del color del tallo, el pecíolo y el pico de la bráctea, fueron designados como Ptla y Psmb, Ptla y Ptlb y Ptla y Pbtb. El gen Ptla es común para todas las tres propiedades.

\section{GÈNE PLÉIOTROPIQUE ET SON INFLUENCE SUR LA PIGMENTATION DE LA TIGE, DU PÉTIOLE ET DU SOMMET DE LA BRACTÉE DANS LE TOURNESOL (Helianthus annuus L.)}

\section{RÉSUMÉ}

La transmission de la couleur de la tige, du pétiole et du sommet de la bractée a été étudiée dans le croisement $c m s-103 \mathrm{~A} \times$ PFNB-2. Les études $\mathrm{F}_{1}$ ont démontré que la couleur violette de la tige du pétiole et du sommet de la bractée était dominante par rapport à la couleur verte de ces parties de la plante. Pour ce qui est de ces caractéristiques, une action complémentaire du gène a été observée en $\mathrm{F}_{2}$. Les gènes qui gèrent la transmission de la couleur de la tige, du pétiole et du sommet de la bractée ont été respectivement désignés comme Ptla et Psmb, Ptla et Ptlb et Ptla et Pbtb. Le gène Ptla est commun aux trois caractéristiques. 
